\title{
Persepsi Guru Paud tentang Attention Deficit Hyperactivity Disorder (ADHD) pada Anak Usia Prasekolah (3-6 Tahun)
}

\author{
I Made Sudarma Adiputra ${ }^{1}$, Ni Luh Ayu Yustikarini ${ }^{2}$, Istri Dalem Hana Yundari ${ }^{3}$, \\ Ni Wayan Trisnadewi ${ }^{4}$, Ni Putu Wiwik Oktaviani ${ }^{5}$ \\ ${ }^{1-3,5}$ STIKes Wira Medika Bali ${ }^{4}$ Program Studi S3 Ilmu Kedokteran, Universitas Udayana Bali \\ Email:dharma_adiputra@yahoo.com
}

Submitted : 09/07/2020

Accepted: 06/01/2021

Published: 06/03/2021

\begin{abstract}
Attention Deficit Hyperactivity Disorder (ADHD) is a child who experiences obstacles in focusing attention, this condition is known as a hyperactive child term. PAUD teachers play an important role in ADHD child detection efforts, as teachers are often the first to see if their students have a keen behavioral difference when compared to other students. The study aims to get an overview of the Paud Teacher's perception of Attention Deficit Hyperactivity Disorder (ADHD) in preschoolaged children (3-6 years). This research uses qualitative research methods with a phenomenological approach. Data was obtained with an in-depth interview of 4 participants using the purposive sampling technique. The analysis used in this research is Colaizzi Analysis 7 step process. The results of the study getting five themes are facing the problem of ADHD children, planning problem solving, seeking support facing ADHD children, taking a positive meaning and accepting responsibility. Based on this research, it can be concluded that to optimize the child's growth, a teacher provides a special education in the form of wholeheartedly educating, patiently facing the child and giving more attention.
\end{abstract}

Keywords: $A D H D$, preschoolers, teacher's perception

\begin{abstract}
Abstrak
Attention Deficit Hyperactivity Disorder (ADHD) adalah anak yang mengalami hambatan dalam memfokuskan perhatian, kondisi ini dikenal dengan istilah anak hiperaktif. Guru PAUD berperan penting dalam upaya pendeteksian anak ADHD, karena guru sering kali menjadi orang pertama yang dapat melihat jika siswanya memiliki perbedaan perilaku yang tajam jika dibandingkan dengan siswa-siswa yang lain. Penelitian ini bertujuan untuk mendapat gambaran persepsi guru paud tentang Attention Deficit Hyperactivity Disorder (ADHD) pada anak usia prasekolah (3-6 tahun). Penelitian ini menggunakan metode penelitian deskriptif kualitatif dengan pendekatan fenomenologi. Data didapatkan dengan wawancara mendalam terhadap 4 partisipan menggunakan teknik purposive sampling. Analisis yang digunakan dalam penelitian ini yaitu analisis colaizzi 7 step process.Hasil penelitian mendapatkan lima tema yaitu menghadapi masalah anak ADHD, merencanakan pemecahan masalah, mencari dukungan menghadapi anak ADHD, mengambil makna positif dan menerima tanggung jawab.Berdasarkan penelitian ini dapat disimpulkan bahwa untuk mengoptimalkan tumbuh kembang anak seorang guru memberikan pendidikan khusus berupa mendidik sepenuh hati, dengan sabar menghadapi anak dan memberikan perhatian yang lebih.
\end{abstract}

Kata Kunci : ADHD, anak usia prasekolah, persepsi guru

\section{PENDAHULUAN}

Anak usia prasekolah adalah anakanak yang berusia 3-6 tahun, pada usia ini biasanya anak mengikuti program prasekolah atau Taman Kanak-kanak. Usia prasekolah merupakan salah satu periode penting, dimana pada masa ini seluruh

aspek perkembangan kecerdasan tumbuh dan berkembang sangat luar biasa(Soetjiningsih, 2012). Pada masa perkembangan berbagaimasalah klinis yang dapat ditemukan pada anak prasekolah, salah satunya adalah anak dengan gangguan 
perkembangan yang cenderung bertingkah hiperaktif atau tidak bisa diam dan kurangnya pemusatan perhatian yang biasadisebutdenganAttention Deficit Hyperactivity Disorder (ADHD) (Chrisna, 2014).

Attention Deficit Hiperactivity Disorder (ADHD) ataudalambahasa Indonesia disebutGangguan Pemusatan Perhatian dan Hiperaktif (GPPH) adalah gangguan perilaku yang ditandai dengan ketidakmampuan dalam memusatkan perhatian dan konsentrasi, impulsivitas dan hiperaktivitas (Paternotte, A., \& Buitelaar, 2010).

Beberapa faktor yang dapat menyebabkan ADHD antara lain factor genetik, factor fungsiotak dan fator lingkungan (Paternotte, A., \& Buitelaar, 2010).Penelitian terbaru mengatakan bahwa factor resiko ADHD juga dapat disebabkan oleh riwayat berat badan lahir rendah (BBLR). Anak yang memilikiriwayatberat badan lahir rendah (BBLR) dapat meningkatkan risiko mengalami ADHD, karena berkaitan dengan gangguan fungsi otak yang sering dijumpai pada anakdengan riwayat ADHD (I Made Sudarma Adiputra, Sutarga and Pinatih, 2015) ADHD merupakan gangguan biologis pada otak yang berlangsung secara kronis sehingga dapat mengakibatkan terganggunya perkembangan anak dalam halkognitif, perilaku, sosial, dan komunikasi(Ayu et al., 2019).

ADHD adalah salah satugangguan yang paling umum terjadi pada anak usia dini (Afeti and Nyarko, 2017). Anak dengan ADHD juga dikenal sebagai anak yang nakal, sering membuat keributan di kelas, sulit diatur dan kebanyakan dari mereka juga memiliki prestasi akademik yang buruk, sehingga membutuhkan penanganan dan bimbingan yang tepat untuk menghadapi anak ADHD di sekolah (Davidson, G.C., Neale, J.M., \& Kring, 2014)
Prevalensi ADHD di dunia sebesar 7,2\%(Thomas et al., 2015), di China prevalensi ADHD mencapai 6,26\%(Wang et al., 2017). Berdasarkan Survey yang dilakukanNational Survey of Children's Health (NSCH) di Amerika Serikat pada tahun 2016 menyatakan bahwa pada anak usia 2-17 tahun terdapat 9,4\% atau sekitar 6,1 juta anak yang sudah didiagnosis ADHD dengan 388.000 anakusia 2-5 tahun, 2,4 juta anak usia 6-11 tahun dan 3,3 juta anak usia 12-17 tahun(Danielson, Bitsko and Holbrook, 2019).

Berdasarkan American Psychiatric Association menyatakan dalam Diagnostic and Statistical Manual of Mental Disorder (DSM-V) bahwa 5\% anak memiliki ADHD. Sekitar 11\% anak usia 5-17 tahun (6,4 juta) telah didiagnosis dengan ADHD pada tahun 2011. Presentasi anak dengan diagnosis ADHD terus meningkat dari 7,8\% pada tahun 2003 hingga 9,5\% tahun 2007 dan $11 \%$ tahun 2011. Sedangkan perbandingan antara anak laki-laki $(13,2 \%)$ lebih banyak jika dibandingkan dengan anak perempuan $(5,6 \%)$ yang di diagnosis dengan ADHD (American Psychiatric Association, 2013),

Berdasarkan penelitian yang dilakukan oleh Sulemba., et al(2016)menyatakan bahwa dari 20 sekolah dasar di Manado menunjukkan bahwa 611 anakdari 5.752 responden mengalami ADHD dengan rincian 16 orang berusia 6 tahun, 91 orang berusia 7 tahun, 99 orang berusia 8 tahun, 82 orang berusia 9 tahun, 107 orang berusia 10 tahun, 9 orang berusia 11 tahun, dan 24 orang berusia 12 tahun. 385 orang berjenis kelamin laki-laki dan 266 orang berjenis kelamin perempuan(Sulemba, Kaunang and Dundu, 2016).

Angka kejadian ADHD di Bali khususnya Kota Denpasar laporan mengenai angka kejadian ADHD hanya bersumber dari laporan kasus di poliklinik atau pusat terapi tumbuh kembang anak. Berdasarkan hasil penelitian yang 
dilakukan Indrayani dkk, denganj udul prevalensi dan faktor-faktor risiko gangguan pemusatan perhatian anak dan hiperaktivitas di klinik tumbuh kembang RSUP Sanglah Denpasar, dalamArningsih (2016)diperoleh hasil dari penelitian tersebu tdari 111 subjek didapatkan prevalensi ADHD 52 (45,9\%) yang terdiridari $43(38,7 \%)$ laki-laki dan 8 (7,2\%) perempuan. Jumlah ADHD tipe kombinasi 39 (76,5\%), ADHD tipe kurang perhatian $7(13,7 \%)$, dan ADHD tipe impulsivitas-hiperaktivitas sebesar 5 $(9,8 \%)$, anak pertama lebih banyak didapatkan pada anak dengan ADHD dan ibu yang pendidikan sarjana (Arningsih, 2016).

Berdasarkan hasil penelitian lain yang dilakukan di 15 sekolah inklusi Kota Denpasar ditemukan 164 siswa-siswi ABK didapatkan anak dengan ADHD sebanyak 58 orang dengan jumlah laki-laki 49 orang dan perempuan 9 orang (Apriliya, 2017). Sedangkan berdasarkan hasil penelitian yang dilakukan oleh Adiputra., et,al (2015)selama tahun 2012 jumlah pasien ADHD yang berkunjung kepoliklinik Tumbuh Kembang RSUP Sanglah Denpasar sebanyak 63 orang, sedangkan kunjungan anak ADHD di Pusat Terapi Anak dan Sekolah Kebutuhan Khusus Pradnyagama Denpasar selama 2012 mencapai 150 anak.

Banyaknya kasus ADHD yang ditemukan pada anak usia dini terutama seringterjadi masalah di lingkungan sekolah maupun rumah menimbulkan dampak ADHD yang mungkinmuncul yaitu prestasi belajarburuk, gizi buruk dan tidak mempunyai teman(Azmira, 2015). Untuk mengatasi hal tersebut peran guru PAUD sangat diperlukan untuk membantu orang tua, khususnya mereka yang masih awam dalam mencari dan mendapatkan informasi terkait (Wiyani, 2014). Guru PAUD berperan penting dalam upaya pendeteksian anak ADHD, karena guru sering kali menjadi orang pertama yang dapat melihat jika siswanya memiliki perbedaan perilaku yang tajam jika dibandingkan dengan siswa-siswa yang lain (Paternotte, A., \& Buitelaar, 2010).

Berdasarkan dari hasil wawancara yang dilakukan pada tanggal 26 Desember 2019 di Pusat PAUD Kumara Bhuana II terhadap 2 guru sebagai informan diperoleh bahwa guru dengan inisial A mengatakan anak ADHD adalah anak yang hiperaktif dan yang tidakbisa diam, saat pembelajaran di kelas mulai anak tersebut hanya ingin bermain di luar dan tidak mau untuk belajar di kelas. Penyebab dari ADHD karena factor genetik dan pengaruh lingkungan. Gejaladari ADHD adalah tidak bisa diam dan sering mengganggu teman yang lain di kelas. Guru tidak bias untuk mendeteksi anak dengan ADHD. Guru cukup kesulitan dalam penanganan dan teknikmengajar pada anakdengan ADHD. Sedangkan guru dengan inisial B mengatakan ADHD adalah anak yang nakal dan sulit untuk diatur di kelas. Penyebab dari ADHD karena factor genetik dan kurang perhatian dari orangtua. Gejala dari ADHD adalah sulit untuk berkonsentrasi dan tidak bisa diam. Cara mendeteksi anak ADHD dengan melihat tingkahlakunya yang hiperaktif dan sulit berkonsentrasi. Cukup kesulitan dalam penanganan dan teknik mengajar pada anak dengan ADHD karena harus focus dengan anak tersebut agar anak tersebut tidak keluar kelas dan mengganggu temannya.

Guru mempunyaipandangan yang berbeda terhadap setiap karakteristik anak di kelas, terutama pada anak hiperaktif. Kenyataan tersebut memunculkan persepsi guru terhadap anak hiperaktif (Haryatiningsih, 2015). Persepsi merupakan proses yang diterimanya stimulus oleh individu melalui alat indera. Proses persepsi tidak lepas dari proses penginderaan (walgito, 2010).

Berdasarkan uraian latar belakang di atas, maka peneliti tertarik untuk melakukan penelitian lebih lanjut tentang "Persepsi Guru PAUD Tentang Attention 
Deficit Hyperactivity Disorder (ADHD) Pada Anak Usia Prasekolah (3-6 Tahun) di Pusat PAUD Kumara Bhuana II".

\section{METODE PENELITIAN}

Penelitian ini menggunakan metode penelitian deskriptif kualitatif dengan pendekatan fenomenologi. Penelitian ini dilakukan di Pusat PAUD Kumara Bhuana II pada bulan Maret 2020. Partisipan pada penelitian ini adalah guru PAUD di Pusat PAUD Kumara Bhuana II dengan jumlah 4 partisipan. Data didapatkan dengan wawancara mendalam terhadap 4 partisipan menggunakan teknik purposive sampling. Analisis yang digunakan dalam penelitian ini yaitu analisis colaizzi 7 step process.

\section{HASIL DAN PEMBAHASAN \\ 1. Gambaran Tempat Penelitian}

Penelitian ini dilakukan di Pusat PAUD Kumara Bhuana II, dimana Pusat PAUD Kumara Bhuana II ini berlokasi di Jl. Antasura, Peguyangan Kangin, Kec. Denpasar Utara. Pusat PAUD Kumara Bhuana II. Visi dari sekolah yaitu terwujudnya anak yang sehat, cerdas ceria, berbudi luhur serta memiliki kesiapan fisik dan mental dalam memasuki pendidikan dan kehidupan selanjutnya. Pusat PAUD Kumara Bhuana II memiliki jumlah ketenagaan sebanyak 18 guru.

Program pendidikan yang ada di sekolah ini terdiri dari PAUD (Pendidikan Anak Usia Dini) dan TK (Taman Kanakkanak). Jumlah siswa dari PAUD sebanyak 9 orang siswa dan jumlah siswa TK sebanyak 197 orang siswa. Dari 9 orang siswa PAUD yaitu 3 siswa memiliki gejala Attention Deficit Hyperactivity Disorder.

\section{Karakteristik Partisipan}

Partisipan dalam penelitian ini adalah Guru PAUD yang bekerja di Pusat PAUD Kumara Bhuana II sejumlah empat partisipan

\section{Hasil Penelitian dan Pembahasan}

Berdasarkan hasil wawancara deng empat partisipan menemukan lima tema utama yang menggambarkan Persepsi Guru PAUD Tentang Attention Deficit Hyperactivity Disorder (ADHD) Pada Anak Usia Prasekolah (3-6 Tahun) di Pusat PAUD Kumara Bhuana II. Adapun tema yang berhasil teridentifikasi dari penelitian iniyaitu (1) Menghadapi masalah anak ADHD, (2) Merencanakan pemecahan masalah, (3) Mencari dukungan menghadapi anak ADHD, (4) Mengambil makna positif keberadaan anak hiperaktif, (5) Menerima tanggung jawab.Kelima tema ini mempunyai sub bab tersendiri, berikut akan dijelaskan pembahasan secara lebih rinci.

\section{Tema 1 : Menghadapi Masalah Anak ADHD}

1. Sub Tema: Memiliki Pengetahuan Terkait Hiperaktif

Memiliki pengetahuan terkait hiperaktifsangat diperlukan guru dalam mendidik anak yang mengalami kelainan. Dikategorikan menjadi mengetahui definisi terkait Attention Deficit Hyperactivity Disorder(ADHD), mengenal penyebab dan tanda gejala, mencari informasi mengenai anak Attention Deficit Hyperactivity Disorder (ADHD). Mengetahui definisi terkaitAttention Deficit Hyperactivity Disorder (ADHD) diungkapan oleh keempat partisipan dalam petikan sebagai berikut :

"Iya dari gerak gerik nya kalau anak hiperaktif itu, hmmmm memang sangat aktif sekali... lain dari anak-anak pada umum nya. Jarang sekali di kasi tahu langsung diem...pernah ibuk baca buku tumbuh kembang, iya salah satu masalah yang paling dominan anak hiperaktif yaitu asik dengan dunia nya."

$$
\text { (P1L17-23) }
$$

"Menurut ibuk,, hmmm anak hiperaktif itu ya anak perhatiannya kurang, agak nakal, susah di atur"

$$
\text { (P2L15-17) }
$$

"Pengalaman dari sebelumnya, menurut ibuk anak hiperaktif membutuhkan 
penangan yang khusus dari pada tementemen nya dan orang tua harus benerbener telaten mengasuh nya"

$$
\text { (P3L15-19) }
$$

"Pandangan ibuk sih anak hiperaktif itu, selama ibuk mengajar ya, anak yang membutuhkan perhatian lebih, karena hmmmm anaknya lain perilakunya, seperti ibuk guru lain yang bilang, sangat aktif, sulit diatur, susah konsentrasi, main sama temen-temen nya sulit hmmmm karena asik main sendiri kadangkadang."

$$
\text { (P4L15-21) }
$$

Mengenal penyebab dan tanda gejala hiperaktif diungkapkan oleh keempat partisipan. Secara pasti partisipan tidak mengetahui penyebab dan tanda gejalanya namun mereka memperkirakan terjadinya perilaku anak hiperaktif berdasarkan apa yang mereka hadapi dan yang dialami oleh orang tua anak seperti disampaikan oleh partisipan berikut ini :

"Dari orang tuanya sih bilang, hmmm apa namanya lambat ngomong, merangkak pun dia gak bisa. Merangkak ten dapet niki langsung jalan. Mmm... tapi lambat jalannya"

$$
\text { (P1L32-35) }
$$

"Dari riwayat orang tuanya....pokonya dia serba lambat dulu, buang - buang gini, gelas, apa yang ada...di bilang hiperaktif aja dah dulu... nggak bisa diem."

$$
\text { (P2L18-20) }
$$

"Pandangannya tu jauh dia, sukak bengong gitu, temen-temen nya asik belajar di ganggu sama dia, aktif jarang mau ngedengerin sekali dua kali."

(P3L19-21)

"Sulit diatur, susah konsentrasi, main sama temen-temen nya sulit hmmmm karena asik main sendiri kadangkadang."

$$
\text { (P4L41-43) }
$$

Menurut Adiputra., et,al (2015), mengungkapkan bahwa faktor resiko ADHD juga dapat disebabkan oleh riwayat berat badan lahir rendah (BBLR). Anak yang memiliki riwayat berat badan lahir rendah (BBLR) dapat menyebabkan meningkatnya risiko mengalami ADHD, karena berkaitan dengan gangguan fungsi otak yang sering dijumpai pada anak dengan riwayat ADHD.

Sedangkan

menurutAzmira, (2015)mengungkapkan bahwa penyebab hiperaktif disebabkan oleh beberapa faktor yaitu faktor genetik, faktor neurotransmitter, faktor neuro-fisiologis, faktor neuro - anatomi, faktor psikososial dan faktor lingkungan. Semua faktor predisposisi tersebut kemungkinan bisa menyebabkan seorang anak menderita hiperaktif. Anak hiperaktif cenderung pendiam dan suka melamun sehingga saat seseorang mengajaknya berkomunikasi dan biasanya dia tidak sanggup menanggapi(Azmira, 2015).

$$
\text { Menurut Ayu et al., }
$$
(2019)mengungkapkan bahwa ADHD merupakan gangguan biologis pada otak yang berlangsung secara kronis sehingga dapat mengakibatkan terganggunya perkembangan anak dalam hal kognitif, perilaku, sosial, dan komunikasi. ADHD memiliki asal yang multifaktorial, yang dihasilkan dari interaksi kompleks dari faktor risiko biologis dan lingkungan(Ayu et al., 2019).

MenurutChrisna, (2014)anak dengan ADHD memiliki gangguan perilaku berupa tindakan yang tidak disertai dengan pemikiran. Mereka seringkali dikuasai oleh perasaannya sehingga akan sangat cepat bereaksi. Mereka juga akan sulit untuk memberi prioritas kegiatan yang dilakukan, sulit untuk mempertimbangkan atau memikirkan terlebih dahulu perilaku yang akan ditampilkan. Gejala ini ditandai dengan kesulitan anak untuk menunda respon, Sisi lain dari impulsif adalah anak berpotensi tinggi untuk melakukan aktivitas yang berbahaya, baik bagi dirinya sendiri maupun orang lain. 
Diperkuat oleh penelitian yang dilakukan oleh (Wiyani, 2014)yang mengungkapkan bahwa gejala ADHD biasanya muncul pada masa prasekolah atau TK dengan ditandai dengan adanya perilaku negatif yang selalu mengundang reaksi dari lingkungannya, banyaknya orang yang menyebut anak yang mengalami ADHD sebagai anak pengganggu, sulit didisiplinkan, selalu merusak benda-benda, dan dianggap sebagai anak yang aneh. ADHD biasanya lebih sering terjadi pada anak usia dini dan usia sekolah. Anak dengan ADHD juga dikenal sebagai anak yang nakal, sering membuat keributan di kelas, sulit diatur dan kebanyakan dari mereka juga memiliki prestasi akademik yang buruk, sehingga membutuhkan penanganan dan bimbingan yang tepat untuk menghadapi anak ADHD di sekolah

Pada penelitian ini, didapatkan bahwa partisipan tidak mengetahui secara pasti penyebab hiperaktif dari anak namun dari pengalaman partisipan menyebutkan bahwa anak mereka mengalami hiperaktif karena sakit. Begitu pula dengan tanda gejala dari anak hiperaktif didapatkan bahwa anak tidak peduli dengan rangsangan luar, suka melamun dan bengong, lambat dalam berbicara dan sangat aktif sulit untuk di atur. Hal tersebut sesuai dengan kajian teori yang diungkapkan olehAdiputra., et,al (2015), (Ayu et al., 2019),(Chrisna, 2014)dan diperkuat dari penelitian yang dilakukan oleh Wiyani (2014)yang mengungkapkan hal serupa sesuai dengan apa yang dirasakan oleh partisipan(Wiyani, 2014).

Upaya untuk mencari informasi yang dilakukan oleh keempat partisipan dalam menghadapi permasalahan yang menyebabkan stres pada saat mendidik anak hiperaktif digambarkan dalam petikan transkrip berikut ini :

"Kebetulan kemarin ada mahasiswa UNUD penelitian juga disini... ya penelitian tumbuh kembang anak. jadi tau sedikit cara mendampingi anak hiperaktif.."

(P1L51-53)

"Di jelasin dia gini gini bahwa dia ini hiperaktif gitu. Tapi kalau IQ di bilang IQ rendah"

$$
\text { (P2L26-28) }
$$

"Iya sempet juga.. cari informasi di google, buku-buku pedomanan anak berkebutuhan khusus.."

$$
\text { (P3L43-45) }
$$

"Kalau tyang sih di kasi tau sama anak... kebetulan anak tyang sekolah di psikolog... jadi dijelasin apa itu anak hiperaktif, ciri-ciri nya bagaimana truss hmmmm anak itu bakalan susah di atur dan harus memberikan perhatian lebih untuk si anak yang mengalami hiperaktif"

(P4L48-54)

Hasil penelitian mengenai mencari dukungan sosial berupa bantuan informasi dari orang lain untuk membantu dalam menyelesaikan permasalahan yang menyababkan stres pada saat mendidik anak hiperaktif dapat diperkuat dengan teori yang disampaikan oleh Nasir \& Muhith, (2011),yang menyatakan bahwa mencari dukungan sosial merupakan tindak lanjut dalam menjelaskan masalah yang dihadapi ketika masalah itu belum terselesaikan. Hal ini tidak lepas dari keterbatasan manusia dalam menyelesaikan masalah yang dihadapi. Tidak semua orang mampu menyelesaikan masalahnya sendiri. Hal ini terjadi karena rumitnya masalah yang dihadapi. Sebagai makhluk sosial, bila seseorang mempunyai masalah yang tidak mampu diselesaikannya sendiri, seharusnya tidak disimpan sendiri dalam fikirannya, namun carilah dukungandari orang lain yang dapat dipercaya dan mampu memberikan bantuan dalam bentuk masukan dan saran dalam menyelesaikan masalah yang dihadapi tersebut. Semakin banyak dukungan dari orang lain, maka semakin efektif upaya penyelesaian masalahnya(Nasir \& Muhith, 2011). 
Dalam penelitian ini, ketika partisipan tidak dapat seorang diri menghadapi permasalahan yang menyebabkan stres pada saat mendidik anak hiperaktif, partisipan mencari dukungan sosial dengan cara mencari bantuan informasi dari dokter agar dapat mengetahui tindakan apa yang selanjutnya dapat dilakukan. Bantuan informasi yang dicari partisipan ini digunakan untuk membantu partisipan dalam menyelesaikan permasalahan yang menyebabkan stres pada saat mendidik anak hiperaktif. Hal tersebut sesuai dengan kajian teori yang diungkapkan oleh Nasir \& Muhith, (2011)yang mengungkapakan hal serupa.

2. Sub Tema : Memenuhi Kebutuhan Pendidikan Anak

Pendidikan formal prasekolah sebagai tempat yang menarik untuk mengembangkan diri bagi anak yang mengalami hiperaktif. Pengalaman yang diperoleh di sekolah akan membantu anak memperoleh perasaan tentang identitas personal, harga diri dan kesenangan. Lingkungan sekolah memberi kepada anak dasar kehidupan dalam perkembangan keterampilan fisik, akademis dan kemampuan. Pada penelitian ini semua parisipan mengungkapkan memberikan anaknya kebutuhan pendidikan di sekolah, berikut ungkapan-ungkapan dari partisipan terkait hal tersebut :

"Iya namanya juga anak-anak.. harus kita didik sepenuh hati dengan sabar gek"

$$
\text { (P1L64-65) }
$$

"Ngasi tahu nya itu harus pelan-pelan... hmmmmm di ajarin gambar-gambar pelan-pelan biar fokus dia...kasi perhatian yang lebih"

$$
\text { (P2L53-56) }
$$

"Kalo ibuk mendampingi dia... lebih lah dari anak-anak lain nya dik"

(P3L69-70)
"Hmm kalo tyang tetep memberikan
perhatian lebih lah kalo di

sekolah...waktu belajar, waktu bermain sama temen-temen nya"

$$
\text { (P4L65-67) }
$$

Menurut (2010)mengungkapkan bahwa secara praktis anak hiperaktif tentu memerlukan penanganan yang khusus, seperti perhatian yang ekstra khusus, memasukan anak ke sekolah khusus pula, intervensi dini dan sebagainya. Tindakan ini perlu dilakukan karena intelegensi dan kemampuannya yang berbeda yaitu pendidikan khusus, pengasuhan orang tua yang khusus juga(Napolion K, 2010).

Menurut Selikowitz, (2001)sebagai guru patut memang berusaha mengupayakan anak sebagaimana mungkin agar anak lebih menjadi lebih baik. Walaupun keadaan anak tidak sebagaimana mestinya namun pendidikan untuk anak tersebut tetap diberikan. Namun ada beberapa fenomena yang terjadi di masyarakat, keluarga telah memberikan dukungan pada anak yang mengalami hiperaktif, dapat menerima keadaan anak tersebut apa adanya. Seluruh anggota keluarga membesarkan, mendidik anak dengan hiperaktif secara bersama-sama di rumah sendiri dan menganggap anak yang menderita hiperaktif itu merupakan bagian dari anggota keluarga, mereka selalu memberikan lingkungan yang penuh kasih sayang dan tak henti-hentinya memberikan rangsangan kepada anak dengan hiperaktif tersebut untuk tumbuh dan belajar, sehingga tumbuh kembang anak yang mengalami hiperaktif di keluarga dapat berjalan hampir seperti anak normal(Selikowitz, 2001).

Pernyataan tersebut diperkuat dalam PP No. 72 (1991) dalam penelitian yang dilakukan olehSeptodia, (2012)mengungkapkan bahwa pendidikan sekolah bertujuan membantu peserta didik yang menyandang kelainan mental agar mampu mengambangkan sikap, pengetahuan dan keterampilan sebagai pribadi maupun anggota masyarakat dalam 
mengadakan hubungan timbal-balik dengan lingkungan sosial, budaya dan alam sekitar, serta dapat mengembangkan kemampuan dalam dunia kerja atau mengikuti.

Pada penelitian ini, didapatkan bahwa untuk mengoptimalkan tumbuh kembang anak, di sekolah anak dapat diajarkan berbagai hal oleh seorang guru dimana anak mendapat pelajaran baik berupa menggambar, menulis dan anak sedikit demi sedikit akan beradaptasi dengan teman sebaya dan kondisi lingkungan di sekolah. Hal tersebut sesuai sesuai dengan kajian teori menyatakan bahwa secara praktis anak hiperaktif tentu memerlukan tindakan yang khusus, seperti perhatian yang ekstra khusus. Diperkuat dalam PP No. 72 (1991) dalam penelitian yang dilakukan oleh Septodia, (2012), yang juga menyatakan hal serupa.

3. Sub Tema: Memanfaatkan Pelayanan Kesehatan

Dengan mengetahui kondisi anak saat itu, guru kelas menyarankan orang tua mengambil tindakan dengan memanfaatkan pelayanan kesehatan. Memanfaatkan pelayanan kesehatan dikategorikan menjadi 2 bagian yaitu medis dan terapi. Pernyataan partisipan yang mengungkapkan orang tua pernah membawa anaknya ke pelayanan kesehatan medis digambarkan dalam pernyataan-pernyataan sebagai berikut:

"Kata orang tuanya sempet di bawa ke ke Sanglah ke tumbuh kembangnya"

(P1L83-85)

"Ke dokter anak sempet, orang tua Si A bilang pas kemaren sempet ngobrol sama ibuk"

Pernyataan partisipan
mengungkapkan orang tua pernah
membawa anaknya ke pelayanan terapi,
digambarkan dalam pernyataan sebagai
berikut:
"Dapat terapi juga ke ke Soetjiningsih
yang di jalan Merdeka itu."

(P3L92-93)
"Dapat terapi, ada setahun... Terapi konsentrasi, terapi ngomong"

$$
\text { (P4L88-89) }
$$

Menurut Yuwono (2012), hampir semua orang tua yang memiliki anakhiperaktif cenderung memiliki masa kritis ketika menghadapi kenyataan bahwa anaknya mengalami suatu gangguan tumbuh kembang. Reaksi awal orang tua umumnya terkejut dan tidak percaya. Krisis ini muncul dikarenakan reaksi-reaksi dari orang tua dan orang sekitarnya, misalnya menolak dan tidak diperbolehkan melakukan terapi atau kebalikannya mencari terapi secara membabi buta dengan harapan mendapatkan "penyembuhan" bagi keadaan anaknya. Keterlibatan orang tua dapat termanifestasikan dalam proses penanganan, pemberian pembelajaran/terapi, pemberian informasi, pembuatan program anak, menentukan kapan harus di terapi, memilih dokter, bidan, psikolog, para terapis dan pengobatan alternatif yang sesuai kebutuhan oleh anak.

$$
\text { Menurut Ayu et al., }
$$
(2019)penatalaksanaan ADHD saat ini yaitu perawatan yang tersedia berfokus pada pengurangan gejala ADHD dan peningkatan fungsi. Perawatan termasuk obat-obatan, berbagai jenis psikoterapi, pendidikan atau pelatihan, atau kombinasi dari perawatan. Perawatan dapat meredakan gejala-gejala gangguan ini, dan kebanyakan berhasil di sekolah serta dapat menjalani kehidupan yang produktif. Obat saat ini tidak menyembuhkan ADHD. Namun, hal ini bisa dikombinasikan dengan menambahkan terapi perilaku, konseling, dan dukungan praktis yang dapat membantu anak-anak dengan ADHD dan keluarga mereka untuk lebih baik dalam mengatasi masalah sehari-hari.

Menurut Winarto, (2013), secara umum tidak ada pengobatan yang dapat dipastikan berhasil memperbaiki gejala secara total. Tetapi perlu diketahui bahwa banyak pengobatan atau terapi yang 
dilakukan ternyata menghasilkan perubahan atau perbaikan gejala misalnya yaitu terapi wicara untuk membantu meningkatkan komunikasi dan kemampuan berbahasa. Terapi occupational untuk membantu integrasi sensoris dan kemampuan motoris. Terapi behaviour untuk memperbaiki kemampuan kognitif. Dan terakhir terapi edukatif untuk pendekatan struktur yang tinggi, biasanya paling tinggi tingkat keberhasilannya.

Pada penelitian ini, didapatkan bahwa beberapa orang tua yang mengetahui keadaan tumbuh kembang anaknya mengalami masalah, orang tua datang ke pelayanan kesehatan yang tersedia, baik pelayanan kesehatan medis berupa bidan, dokter dan membawa ke pelayanan kesehatan terapi dan ada juga orang tua anak mereka ke pengobatan alternatif atau non medis. Hal tersebut sesuai dengan kajian teori yang diungkapkan oleh Yuwono (2012) yang mengungkapkan hal serupa. Diperkuat dengan teori yang diungkapkan oleh Winarto (2013)berpendapat terdapat beberapa terapi dalam upaya perbaikan gejala anak yang mengalami hiperaktif(Yuwono, 2012; Winarto, 2013).

\section{Tema 2 : Merencanakan Pemecahan Masalah}

Sub Tema : Mengoptimalkan Tumbuh Kembang Anak ADHD

Upaya merencanakan pemecahan masalah disampaikan oleh tiga partisipan, yaitu dengan mengoptimalkan tumbuh kembang anak. Tema tersebut dikelompokkan menjadi satu sub tema yaitu mengoptimalkan tumbuh kembang anak dan dikategorikan menjadi memikirkan tindakan yang akan dilakukan dalam mendidik anak di sekolah yaitu digambarkan dalam petikan transkrip partisipan berikut :

"Kalau kita tahu.. hmmm dan ada gejala anak itu mengalami hiperaktif tentu ibuk pasti ngobrol-ngobrol sama orang tua buat....ya nyari - nyari dulu terapi yang bagus, iya kayak di bilang tadi minimal ke tumbuh kembang anak dulu konsulin.... hmmm nanti kalau terlambat kasian si anak..."

$$
\text { (P1L91-96) }
$$

"Iya tentu harus kita optimalkan tumbuh kembang nya... ya seperti gambargambar.. kelompok bermain, sosialisasi sama temen-temennya.. ya kita pasti bantu di sini dik"

\section{(P2L69-72)}

"Selain pendidikan formal gini....peran terapi seperti terapi bicara juga penting menurut ibuk atau ke dokter spesialis tumbuh kembang"

$$
\text { (P4L90-92) }
$$

Hasil penelitian ini dapat diperkuat dengan teori yang disampaikan oleh Lazarus dan Folkman dalam Nasir \& Muhith, (2011), merencanakan pemecahan masalah merupakanusaha untuk mengubah keadaan yang dianggap menekan dengan cara hati-hati, bertahap, dan analitis.

Hasil penelitian ini dapat diperkuat dengan hasil penelitian yang dilakukan oleh Winaswati (2013),yang menyatakan bahwa memikirkan cara untuk menghadapi permasalahan dilakukan dengan cara individu memikirkan dan mempertimbangkan secara matang beberapa alternatif pemecahan masalah yang mungkin dilakukan, meminta pendapat dan pandangan dari orang lain tentang masalah yang dihadapi, bersikap hati-hati sebelum memutuskan sesuatu dan mengevaluasi strategi yang pernah dilakukan. Subjek memiliki berbagai rencana strategi dalam memecahkan hambatan, bagaimana rencana A jika tidak berhasil maka ada rencana $\mathrm{B}$, jika tidak B maka rencana $\mathrm{C}$ dan melakukan evaluasi atas rencana yang telah dilakukan.

Partisipan dalam penelitian ini berfikir sebelum bertindak untuk mengoptimalkan tumbuh kembang anak. Hal tersebut dilakukan agar partisipan dapat membuat rencana dan tidak salah dalam mengambil keputusan. Hal tersebut sesuai 
dengan kajian teori yang mengungkapkan merencanakan pemecahan masalah merupakan usaha untuk mengubah keadaan yang dianggap menekan dengan cara hatihati, bertahap, dan analitis yang dinyatakan oleh Folkman dalam Nasir \& Muhith, (2011). Hal senada juga diperkuat oleh sebuah penelitian yang dilakukan oleh (Winaswati, 2013) yang menyatakan hal serupa.

\section{Tema 3 : Mencari Dukungan Menghadapi Anak ADHD}

Sub Tema : Bantuan Informasi

Mencari dukungan yang dapat membantu guru dalammenghadapi masalah memiliki anak hiperaktif dibagi menjadi dua kategori, yaitu informasi dari teman, dan informasi dari masyarakat.

Guru yang mencari informasi dari teman dalammenghadapi masalah memiliki anak hiperaktif di ungkapkan oleh partisipan 1, berikut pernyataan-pernyataan partisipan terkait mencari informasi dari teman:

"Itu dah terapi yang di Sanglah nike tau nya dari temen - temen di sekolahan, nanya sama temen - temen gitu."

$$
\text { (P1L85-87) }
$$

Guru mencari informasi dari tenaga kesehatan dalam menghadapi masalah memiliki anak hiperaktif diungkapkan oleh partisipan 2 dan partisipan 4. Digambarkan dalam petikan transkrip berikut:

"Ada juga dari mahasiswa UNUD yang magang disini... dapat sedikitnya penjelasan tentang tumbuh kembang anak..."

$$
\text { (P2L73-75) }
$$

"Kemarin mahasiswa UNUD penyuluhan... kebetulan kasusnya sama tentang anak hiperaktif gek..."

(P4L43-44)

Hasil penelitian mengenai mencari dukungan sosial berupa bantuan informasi dari orang lain untuk membantu dalam menyelesaikan permasalahan yang menyababkan stres pada saat merawat anak hiperaktif dapat diperkuat dengan teori yang disampaikan oleh Stuart \& Sundeen dalam Nasir \& Muhith, (2011), yang menyatakan bahwa mencari dukungan sosial atau utilizing social support, merupakan tindak lanjut dalam menjelaskan masalah yang dihadapi ketika masalah itu belum terselesaikan. Hal ini tidak lepas dari keterbatasan manusia dalam menyelesaikan masalah yang dihadapi. Tidak semua orang mampu menyelesaikan masalahnya sendiri. Hal ini terjadi karena rumitnya masalah yang dihadapi. Sebagai makhluk sosial, bila seseorang mempunyai masalah yang tidak mampu diselesaikannya sendiri, seharusnya tidak disimpan sendiri dalam fikirannya, namun carilah dukungan dari orang lain yang dapat dipercaya dan mampu memberikan bantuan dalam bentuk masukan dan saran dalam menyelesaikan masalah yang dihadapi tersebut. Semakin banyak dukungan dari orang lain, maka semakin efektif upaya penyelesaian masalahnya.

Menurut (Priwanti., et al 2019)dukungan sosial berupa dukungan secara verbal yang bersifat memotivasi, menyemangati, serta memberikan saran maupun solusi yang diberikan oleh lingkungan sekitar. Sumber dukungan sosial berasal dari dukungan secara informal dan formal.

Dalam penelitian ini, ketika partisipan tidak dapat seorang diri menghadapi permasalahan yang menyebabkan stres pada saat mengajar anak hiperaktif, partisipan mencari dukungan sosial dengan cara mencari bantuan informasi dari orang lain, baik dari teman maupun dari masyarakat. Bantuan informasi yang dicari partisipan ini digunakan untuk membantu partisipan dalam menyelesaikan permasalahan yang menyebabkan stres pada saat mengajar anak hiperaktif.

\section{Tema 4 : Mengambil Makna Positif} Keberadaan Anak Hiperaktif

Sub Tema: Penilaian Secara Positif

Dalam penelitian ini, partisipan mengambil makna positif dari 
permasalahan yang menyebabkan stres pada saat mendidik anak hiperaktif. Makna positif yang diambil oleh partisipan adalah partisipan belajar untuk menganggap hal tersebut sebagai pembelajaran hidup yang harus dilalui. Ungkapan partisipan yang menganggap hal tersebut sebagai pembelajaran hidup diungkapkan oleh partisipan dua dan partisipan tiga, seperti pernyataan berikut :

"Yaaaa gimana... saya harus mengajari dan merawat anak dengan perhatian lebih sampai besar namanya juga anak, titipan Tuhan..."

$$
\text { (P2L75-77) }
$$

"yaaa ini dah, ini pelajaran hidup..." (P3L82-83)

Hasil penelitian mengenai partisipan mengambil makna positif dari permasalahan saat merawat anak hiperaktif dapat diperkuat dengan teori yang disampaikan oleh Andarini \& Fatma, (2013)memaknai hidup dengan cara mengambil makna positif pada setiap peristiwa, masalah, bahkan penderitaan yang dialaminya adalah orang yang memiliki kecerdasan spritiual yang tinggi. Dengan memberi makna yang positif akan mampu membangkitkan jiwa dan melakukan perbuatan dan tindakan yang positif. Menurut Nasir \& Muhith, (2011), usaha mencari makna positif dari permasalahan dengan berfokus pada pengembangan diri, biasanya juga melibatkan hal-hal yang bersifat religius.

Peneliti berpendapat, setiap permasalahan yang dihadapi pasti ada makna positif yang dapat diambil. Secara sadar atau tidak sadar, permasalahan yang menyebabkan stres pada saat merawat anak hiperaktif dapat mempengaruhi pengembangan kepribadian bagi partisipan dalam melakukan tindakan yang positif.Dalam penelitian ini partisipan menganggap apapun keadaan anak harus tetap dirawat dengan baik

Partisipan memaknai cobaan tersebut sebagai pelajaran hidup yang berharga. Hal tersebut sesuai dengan kajian teori yang diungkapkan oleh Nasir \& Muhith, (2011), serta diperkuat oleh sebuah penelitian yang dilakukan olehAndarini \& Fatma, (2013),yang juga menyatakan hal serupa.

\section{Tema 5 : Menerima Tanggung Jawab}

Sub Tema: Sadar Terhadap Tanggung Jawab

Partisipan dalam penelitian ini menyadari permasalahan yang muncul dan menyebakan stres pada saat mendidik anak hiperaktif ini merupakan tanggung jawab yang harus diselesaikan partisipan sebagai seorang guru. Ungkapan mengenai sadar terhadap tanggung jawab sebagai seorang guru diungkapkan oleh partisipan satu, partisipan dua, partisipan tiga, dan partisipan empat. Seperti pernyataan berikut

"Mmm... tanggung jawab mendidik harus sabar, pokonya hal tersebut harus diutamakan..."

(P1L100-102)

"Semuanya tu saya berusaha....anakanak disini semuanya sama seperti anak ibuk sendiri”,

$$
\text { (P2L105-106) }
$$

"Walaupun susah - susah gitu anak sendiri ya tetap aja saya saya harus berusaha mengajari anak-anak disini"

$$
\text { (P3L26-28) }
$$

"Susah-susah gampang...kuncinya sabar aja gek. Hmmmm"

\section{(P4L69)}

Hasil penelitian mengenai partisipan sadar akan tanggung jawab terhadap permasalahan dapat diperkuat dengan teori yang disampaikan olehAndarini \& Fatma, (2013), menerima tanggung jawab adalah suatu strategi yang pasif dimana individu mengakui atau menerima bahwa dirinya memiliki peran dalam masalah tersebut. Dalam strategi ini individu akan mengkritik diri sendiri bila sedang menghadapi masalah dan merasa dirinyalah yang bertanggung jawab atas masalah yang timbul. Menurut Nasir \& Muhith, (2011), 
usaha untuk menyadari tanggung jawab diri sendiri dalammencoba menerimanya untuk membuat semuanya menjadi lebih baik. Strategi ini baik, terlebih bila masalah terjadi karena fikiran dan tindakan sendiri. Namun, strategi ini menjadi tidak baik bila individu tidak seharusnya tidak bertanggung jawab atas masalah tersebut.

Dalam penelitian ini, partisipan tetap menghadapi permasalahan yang muncul pada saat mendidik anak hiperaktif, walaupun partisipan mengetahui bahwa permasalahan tersebut yang menyebabkan partisipanmenjadi stres. Hal tersebut dikarenakan partisipan sadar terhadap tanggung jawab sebagai seorang guru dalam mengoptimalkan tumbuh kembang anak sehingga partisipan dalam penelitian ini dapat tetap menghadapi permasalahan dalam merawat anak hiperaktif. Hal tersebut sesuai dengan kajian teori yang diungkapkan oleh Nasir \& Muhith, (2011), serta diperkuat oleh sebuah penelitian yang dilakukan oleh Andarini \& Fatma, (2013),yang juga menyatakan hal serupa.

\section{SIMPULAN}

Berdasarkan hasil penelitian tentang Persepsi Guru PAUD TentangAttention Deficit Hyperactivity Disorder (ADHD) Pada Anak UsiaPrasekolah (3-6 Tahun) di Pusat PAUD Kumara Bhuana II ini didapatkan 5 tema yaitu menghadapi masalah anak ADHD, merencanakan pemecahan masalah, mencari dukungan menghadapi anak ADHD, mengambil makna positif dan menerima tanggung jawab. Berdasarkan penelitian ini dapat disimpulkan bahwa untuk mengoptimalkan tumbuh kembang anak seorang guru memberikan pendidikan khusus berupa mendidiksepenuh hati, dengan sabar menghadapi anak dan memberikan perhatian yang lebih.

\section{SARAN}

Berdasarkan penelitian ini disarankan untuk mengoptimalkan tumbuh kembang anak, maka seorang guru memberikan pendidikan khusus berupa mendidik sepenuh hati, dengan sabar menghadapi anak dan memberikan perhatian yang lebih.

\section{DAFTAR PUSTAKA}

Adiputra, I Made Sudarma, Sutarga, I. M., \& Pinatih, G. N. I. (2015). Faktor Risiko Attention Deficit Hyperactivity Disorder (ADHD) pada Anak di Denpasar. Public Health and Preventive Medicine Archive, 3(1), 35. https://doi.org/10.15562/phpma.v3i1.8 4

Afeti, K., \& Nyarko, S. H. (2017). Prevalence and effect of attentiondeficit/hyperactivity disorder on school performance among primary school pupils in the Hohoe Municipality, Ghana. Annals of General Psychiatry, 16(1), 1-7. https://doi.org/10.1186/s12991-0170135-5

American Psychiatric Association. (2013). Diagnostic and Statistic Manual Of Mental Disorder (Fifth edit). Washington: American Psychiatric Association.

Andarini \& Fatma. (2013). Hubungan Antara Distress dan Dukungan Sosial dengan Prokrastinasi Akademik pada Mahasiswa dalam Menyusun Skripsi. Talenta Psikologi, Vol II (2.

Apriliya, L. P. . (2017). Gambaran Angka Kejadian ADHD di Sekolah Inklusi Denpasar Skripsi Tidak Dipublikasikan. Stikes Wira Medika Bali.

Arningsih, A. A. D. . (2016). Hubungan Gangguan Pemusatan Perhatian dan Hiperaktivitas pada Anak Terhadap Kejadian Depresi Ibu di Sekolah Swasta Denpasar. Universitas Udayana Tesis Tidak Dipublikasikan.

Ayu, I., Laksmi, P., Bagus, C., Lesmana, J., Studi, P., Dokter, P., ... Dari, A. (2019). Tingkat Kemandirian Anak Attention Deficit Hyperactivity 
Disorder Dengan Terapi Perilaku Di Yayasan Mentari Fajar Jimbaran Badung Abstrak Perilaku yang mengkhawatirkan orang tua biasanya anak sulit menaruh perhatian atau sulit berkonsentrasi karena anak $l$. $8(5)$.

Azmira, V. (2015). A Gift: Anak Hiperaktif. Yogyakarta: Rapha Publishing.

Chrisna, F. (2014). Terapi dan Bimbingan Menulis untuk Anak ADHD. Yogyakarta: Maxima.

Danielson, M. L., Bitsko, R. H., \& Holbrook, J. R. (2019). Prevalence of Parent-Reported ADHD Diagnosis and Associated Treatment Among U.S. Children and Adolescents, 2016. Journal of Clinical Child \& Adolescent Psycology, 47(2), 199-212. https://doi.org/10.1080/15374416.2017 .1417860.Prevalence

Davidson, G.C., Neale, J.M., \& Kring, A. . (2014). Psokologi Abnormal. Jakarta: PT Raja Grafindo Persada.

Haryatiningsih, R. (2015). Studi kasus anak hiperaktif dan usaha guru dalam memusatkan perhatian beajar siswa di MI Muhamadiyah Ceporan Kabupaten Karanganyar.

Napolion K. (2010). Pengalaman Keluarga Dalam Merawat Anak Tuna Grahita.

Nasir \& Muhith. (2011). Dasar-dasar Keperawatan Jiwa: Pengantar dan Teori. Jakarta: Salemba Medika.

Paternotte, A., \& Buitelaar, J. (2010). Attention Deficit Hyperactivity Disorder (Gangguan Pemusatan Perhatian dan Hiperaktivitas). Jakarta: Prenada.

Priwanti, T. R., Puspitawati, I., \& Fuad, A. (2019). Dukungan Sosial Dan Kepercayaan Diri Pada Orang Tua Dengan Anak Down Syndrome. Jurnal Psikologi, 12(1), 76-87. https://doi.org/10.35760/psi.2019.v12i 1.1918

Selikowitz. (2001). Speech and language therapy for children with down syndrome.

Septodia. (2012). Penerimaan ibu terhadap anaknya yang mengalami down sydrom.

Soetjiningsih, C. H. (2012). Perkembangan Anak Sejak Pembuahan Sampai Dengan Kanak-kanak Akhir. Jakarta: Prenada Media Group.

Sulemba, D. S., Kaunang, T. M. D., \& Dundu, A. E. (2016). Deteksi dini dan interaksi anak gangguan pemusatan perhatian hiperaktivitas dengan orang tua dan saudara kandung pada 20 sekolah dasar Kota Manado. E-CliniC, 4(2).

https://doi.org/10.35790/ecl.4.2.2016.1 2661

Thomas, R., Sanders, S., Doust, J., Beller, E., \& Glasziou, P. (2015). Prevalence of attention-deficit/hyperactivity disorder: A systematic review and meta-analysis. Pediatrics, 135(4), e994-e1001.

https://doi.org/10.1542/peds.20143482

walgito, B. (2010). Pengantar Psikologi Umum. Yogyakarta: CV Andi Offset.

Wang, T., Liu, K., Li, Z., Xu, Y., Liu, Y., Shi, W., \& Chen, L. (2017). Prevalence of attention deficit/hyperactivity disorder among children and adolescents in China: A systematic review and meta-analysis. BMC Psychiatry, 17(1), 1-11. https://doi.org/10.1186/s12888-016$1187-9$

Winarto. (2013). Autisme dan Peran Pangan. Jakarta: PT Gramedia.

Winaswati, M. (2013). Motivasi Berwirausaha pada Penyandang Disabilitas Fisik. Jurnal Falkultas Psykologi.

Wiyani, N. . (2014). Penanganan Anak Usia Dini Berkebutuhan Khusus. Yogyakarta: Ar-Ruz Media.

Yuwono, J. (2012). Memahami anak berkebutuhan Khusus ( Kajian Teoritik dan Empirik). Bandung: Alfabeta. 